\title{
INNOVATION AND INVESTMENT ACTIVITY
}

DOI: https://doi.org/10.30525/978-9934-26-081-0-8

\section{ІННОВАЦЙНИЙ ПОТЕНЦАЛЛ \\ ТА ІННОВАЦЙНА АКТИВНІСТЬ ЯК ПІДГРУНТЯ ВИБОРУ \\ ІННОВАЦИЙНОЇ СТРАТЕГІЇ ТРАНСПОРТНО- ЛОГІСТИЧНОГО ПІДПРИЕМСТВА}

\author{
Комчатних О. В. \\ кандидат економічних наук, \\ старший викладач кафедри економіки \\ Національного транспортного університету \\ м. Київ, Україна
}

Інновації є одним 3 ключових факторів досягнення і підтримки конкурентних переваг на ринку. Вони є однією з вимог сьогодення для ефективного функціонування підприємства на ринку, а також найціннішими активами сучасного підприємства. Ця цінність пов'язана $з$ роллю, яку вони відіграють для підприємства. Вони допомагають не лише поліпшити якість продуктів i послуг підприємства, а також є засобом виживання та розвитку, реагуючи на швидкоплинні тенденції ринку і адаптуючись до вимог споживачів. Тому виникає потреба інноваційного розвитку підприємства, якщо воно не хоче стати аутсайдером ринку.

Комплексною характеристикою здатності підприємства до інновацій традиційно вважається його інноваційний потенціал. Узагальнюючи існуючі підходи до визначення інноваційного потенціалу підприємства, можна зробити висновок, що це органічна складова загальноекономічного потенціалу, що має ідентичну з ним структуру, формується під впливом наявних матеріальних та фінансових ресурсів, інтелектуального капіталу, відображає вже досягнутий рівень інноваційних результатів, i характеризує потенційну здатність підприємства до розвитку за рахунок впровадження досяжних для нього інноваційних рішень. 
Про ефективність використання наявного інноваційного потенціалу свідчить рівень інноваційної активності підприємства, тобто інтенсивність створення, впровадження та просування нових та значно удосконалених рішень. Впровадження інновацій на інноваційно-активних підприємствах $є$ ефективним способом підвищення конкурентоспроможності продуктів, підтримання високих темпів розвитку і досягнення прийнятного рівня доходності.

В загальному розумінні управління підприємством спрямоване на досягнення його цілей. Інструментом досягнення цілей інноваційного розвитку підприємства $є$ інноваційна стратегія. До основних цілей інноваційної діяльності транспортно-логістичних підприємств можна віднести: підвищення якості послуг; адаптацію послуг до потреб споживачів; зниження експлуатаційних витрат підприємства; впровадження екологічного транспорту; підвищення ефективності діяльності підприємства; створення доданої вартості послуг; збільшення ринкової частки підприємства; поліпшення умов праці; поліпшення іміджу підприємства; підвищення гнучкості діяльності; удосконалення системи управління підприємством.

Найбільш точно сутність інноваційної стратегії підприємства передає визначення її як взаємопов'язаного комплексу заходів та дій по ефективному використанню інноваційного потенціалу, що забезпечують досягнення цілей довгострокового розвитку. Принципово важливими $є$ наступні характеристики стратегії: стратегія повинна бути пов'язана $з$ уявленням про майбутнє в досить довгостроковій перспективі; стратегія повинна передбачати поетапне розвертання діяльності, наявність окремих проміжних цілей по кожному етапу і пов'язує всі ці етапи та цілі єдиною основою для прийняття рішень; стратегія повинна враховувати не тільки наявні та доступні відомим способом ресурси, а й передбачає потенційну можливість їх отримання.

При визначенні найбільш привабливої інноваційної стратегії підприємства необхідно дотримуютися певних критеріїв, серед яких найважливішими $є$ : відповідність можливостям і загрозам зовнішнього середовища; відповідність цілям підприємства і сумісність 3 його місією; досягнення конкурентних переваг за рахунок 
використання сильних сторін підприємства та слабкості конкурентів, нейтралізації або компенсації слабких сторін підприємства i сильних сторін (переваг) конкурентів; наявність необхідних ресурсів, наукового, технічного, виробничого, кадрового потенціалів; досягнення балансу між усіма структурними підрозділами підприємства; використання ефекту синергізму інноваційної діяльності як єдиної системи [1].

Для вибору стратегій розвитку підприємств за останні десятиріччя вченими було запропоновано низку різноманітних засобів (методів, моделей тощо), які мали як спільні, так і відмінні риси. Їх можна умовно згрупувати, зокрема, в такі групи [2]:

- матричні - дають можливість вибрати вид стратегії підприємства залежно від значень двох чи більше факторів (матриця SWOT-аналізу, матриця Бостонської консалтингової групи, матриця Дженерал Електрик - МакКінсі, матриця Shell, матриця конкурентних переваг М. Портера, нова матриця Бостонської консалтингової групи та інші);

- графічні - дають змогу за допомогою різноманітних графіків виявити варіанти оптимальних для підприємства стратегій або напрямів подальшого розвитку (модель «кривої досвіду», модель «кривої життєвого циклу попиту», тривимірна схема Абеля, метод SPACE-аналізу та інші);

- аналітичні - дозволяють дослідити вплив різних факторів, як окремо, так і в сукупності на подальший розвиток підприємства i вибір його стратегії; визначити поточне ринкове положення підприємства, перспективи та недоліки в організації його діяльності і управлінні нею тощо (модель МакКінсі 7S, метод аналізу GAP, метод аналізу «Lots», метод COП-аналізу, метод PIMS-аналізу та інші).

Загалом у сучасній теорії управління існує багато прихильників різних підходів до формування стратегії підприємства, однак в науковій літературі їх поділяють на дві групи: «раціоналістичні» підходи, що базуються на плановому прийнятті рішень та «поведінкові» підходи, які грунтуються на швидкій реакції на проблеми, що виникають, з дотриманням критеріїв, прийнятих для встановлених взаємовідносин [3]. 
Проаналізувавши існуючі методичні підходи до формування інноваційної стратегії, вважаємо, що для вибору інноваційної стратегії підприємства доцільно використовувати двовимірну матрицю, яка найбільш доступно відображає можливі варіанти стратегічного розвитку підприємства за заданими параметрами. При дослідженні альтернативних інноваційних стратегій для транспортно-логістичних підприємств, простежується певна закономірність між їх інноваційною активністю та рівнем інноваційного потенціалу (рис. 1):

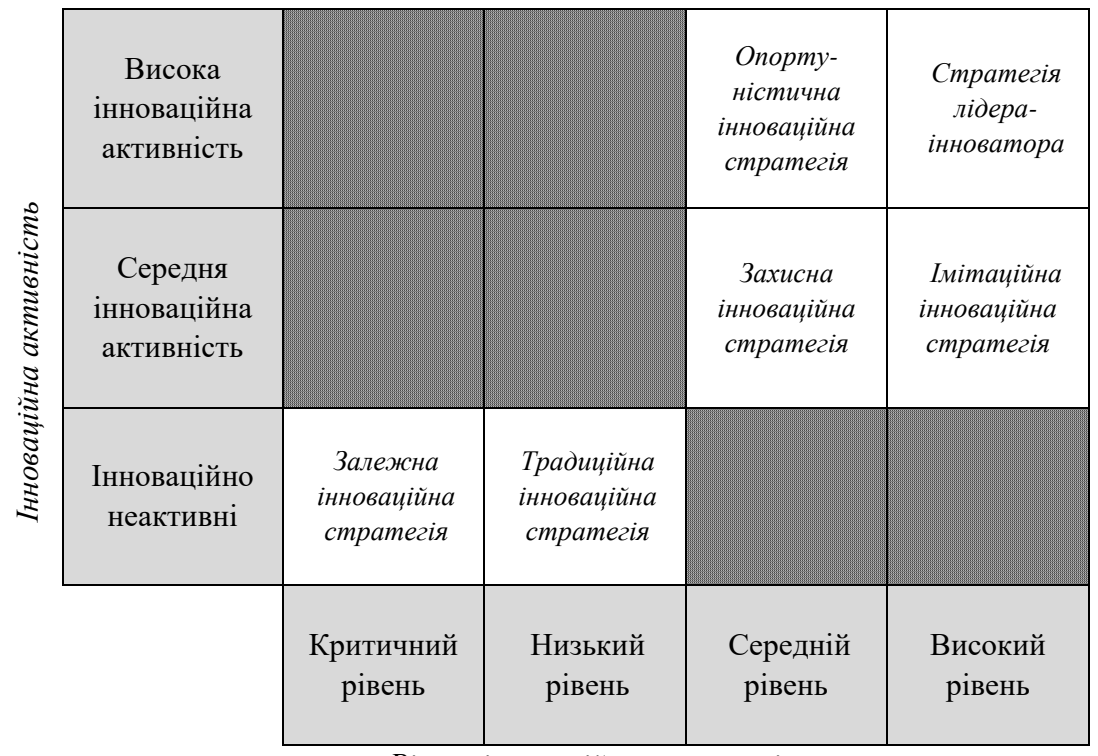

Рівень інноваційного потенціалу

\section{Рис. 1. Матриця альтернатив інноваційних стратегій для транспортно-логістичних підприємств}

- висока інноваційна активність та високий рівень інноваційного потенціалу - стратегія інноваційного лідерства;

- середня інноваційна активність та високий рівень інноваційного потенціалу - імітаційна інноваційна стратегія;

- висока інноваційна активність та середній рівень інноваційного потенціалу - опортуністична інноваційна стратегія; 
- середня інноваційна активність та середній рівень інноваційного потенціалу - захисна інноваційна стратегія;

- відсутність інноваційної активності та низький рівень інноваційного потенціалу - традиційна інноваційна стратегія;

- відсутність інноваційної активності та критичний рівень інноваційного потенціалу - залежна інноваційна стратегія.

Проведений ієрархічний кластерний аналіз транспортнологістичних підприємств [4] показав, що інноваційно неактивні підприємства характеризуються низьким та критичним рівнем інноваційного потенціалу, а інноваційно активні володіють середнім та високим рівнем інноваційного потенціалу. Тому при побудові матриці альтернатив інноваційних стратегій розглядалися лише випадки високого і середнього рівня інноваційного потенціалу для інноваційно активних підприємств та низького і критичного для інноваційно неактивних.

\section{Література:}

1. Краснокутська Н.В. Інноваційний менеджмент : Навч. посібник. Київ : KHEУ, 2003. $504 \mathrm{c}$.

2. Касьян 3.Е. Оцінювання ефективності реалізації інноваційної стратегії промислових підприємств. Наукова-технічна інформаиія. 2012. № 3. С. 24-27.

3. Кіндрацька Г.І. Основи стратегічного менеджменту : навч. пос. Львів : Кінапрі ЛТД, 2000. 235 с.

4. Комчатних О.В. Кластерний аналіз в оцінюванні інноваційного потенціалу підприємств транспортної логістики. Міжнародний науковий журнал «Інтернаука». Серія «Економічні науки». 2019. № 2 (22). С. 31-37. 